\title{
Uji Efektivitas Ekstrak Lidah Mertua (Sansevieria trifasciata) untuk Menyembuhkan Luka Bakar pada Hewan Coba Kelinci (Oryctolagus cuniculus)
}

\section{The Healing of Burns Effectiveness Test of Lidah Mertua extract (Sansevieria trifasciata) on Rabbits (Oryctolagus cuniculus)}

\author{
Ervianingsih, Izal Zahran, Hurria, Novita Imeldha \\ Program Studi S1 Farmasi, Universitas Muhammadiyah Palopo \\ email: ervianingsih@umpalopo.ac.id \\ (tanggal diterima: 15-01-2020 , tanggal disetujui: 05-03-2020)
}

\begin{abstract}
INTISARI
Tanaman Lidah Mertua (Sansevieria Trifasciata) memiliki senyawa aktif Saponin, Polifenol, dan Flavonoid yang mampu bekerja sebagai antibakteri. Saponin dalam ekstrak lidah mertua juga bekerja membantu pembentukan kolagen yang efektif dalam mempercepat proses penyembuhan luka bakar. Penelitian ini bertujuan untuk mengetahui efektivitas penyembuhan luka bakar pada hewan coba kelinci (Oryctolagus cuniculus) dengan menggunakan ekstrak etanol lidah mertua (Sansevieria trifasciata).

Jenis penelitian ini adalah true experiment dimana terdapat 5 perlakuan, yaitu 3 perlakuan dan 2 kontrol dengan konsentrasi $10 \%, 15 \%$, dan 20\%, dan kontrol negatif menggunakan aquadest serta kontrol postif menggunakan bioplacenton. Sampel ini diekstraksi dengan metode maserasi menggunakan etanol 70\%.

Hasil penelitian menunjukkan bahwa ekstrak lidah mertua dapat menyembuhkan luka bakar, hal ini berdasarkan hasil uji anova pada taraf kepercayaan 95\% dimana F hitung (30) $>\mathrm{F}$ tabel $(2,35)$ yang berarti hipotesa diterima. Dilanjutkan dengan uji BNT (Beda Nyata Terkecil) menunjukkan bahwa ekstrak lidah mertua dengan konsentrasi $10 \%$, 15\%, dan $20 \%$ dapat menghasilkan efek yang berbeda nyata, dengan efek yang optimum adalah ekstrak lidah mertua dengan konsentrasi $20 \%$.
\end{abstract}

Kata kunci : ekstrak lidah mertua; luka bakar; kelinci

\begin{abstract}
The Lidah Mertua Plants (Sansevieria trifasciata) have active compounds namely Saponin, Polifenol, and Flavonoids that are able to work as antibacterials. Saponin content in the extracts of lidah mertua also work to help the formation of collagen is effective in accelerating the healing process of burns. The purpose of this study was to determine the effectiveness of healing of burns in rabbit animal experiments (Oryctolagus cuniculus) using ethanol extract of lidah mertua (Sansevieria trifasciata).

The type of this study was pre experiment in which there were 5 treatments, ie 3 treatments and 2 controls with concentrations of $10 \% \mathrm{~b} / \mathrm{v}, 15 \% \mathrm{~b} / \mathrm{v}$, and $20 \% \mathrm{~b} / \mathrm{v}$, and negative control using aquadest and positive control using bioplacenton. This sample was extracted by maceration method using ethanol $70 \%$.

The results showed that the extract of lidah mertua can heal burns, this was based on the results of anova test at the level of $95 \%$ confidence where $\mathrm{F}$ arithmetic (30)> F table (2.35) which means the hypothesis accepted. Followed by the BNT test (Beda Real Smallest) showed that the extract of tongue-in-law with concentration of $10 \% \mathrm{~b} / \mathrm{v}, 15 \% \mathrm{~b} / \mathrm{v}$, and $20 \% \mathrm{~b} / \mathrm{v}$ could produce different effect significantly, with optimum effect was tongue extract with $20 \%$ concentration.
\end{abstract}

Keyword : Lidah Mertua extract ; Healing burns ; Rabbit 


\section{PENDAHULUAN}

Luka bakar adalah cedera terhadap jaringan yang disebabkan oleh kontak terhadap panas kering (api), panas lembab (uap atau cairan panas), kimiawi (seperti bahan-bahan korosif), bahan-bahan elektrik (arus listrik atau lampu), friksi, atau energi elektromagnetik dan radian. Luka bakar merupakan satu jenis trauma yang memiliki morbiditas dan mortalitas yang tinggi sehingga memerlukan perawatan yang khusus mulai fase awal hingga fase lanjut [1].

Luka bakar karena kebakaran merupakan satu dari banyak tipe luka bakar yang paling fatal dan sering terjadi ketika anak bermain dengan korek api dan secara tidak sengaja membuat diri (dan rumah) anak terbakar. Anak berisiko tinggi mengalami luka bakar, sebagian luka bakar terjadi dirumah misalnya pada waktu memasak, memanaskan air atau menggunakan alat listrik yang paling sering menyebabkan kejadian ini. Kecelakaan industri juga dapat menyebabkan luka bakar [2].

Secara umum, luka bakar akan segera mengalami kontaminasi setelah cedera, baik oleh flora endogen atau organisme residen dari fasilitas perawatan [3]. Apabila luka bakar tidak diatasi dengan baik, maka dapat terjadi infeksi. Infeksi luka bakar yang dapat disebabkan oleh banyak hal, salah satunya bakteri. Bakteri yang sering ditemukan pada infeksi luka bakar adalah Staphilococcus aureus dan Pseudomonas aeruginosa [4]. Staphylococcus merupakan organisme penyebab infeksi yang paling dominan, salah satunya pada luka bakar [3].

Salah satu alternatif dalam penyembuhan infeksi luka bakar adalah menggunakan tanaman obat yang memiliki kandungan antibakteri. Antibakteri bekerja menghambat serta membunuh bakteri penyebab infeksi tersebut.

Tanaman lidah mertua (Sansevieria trifasciata) merupakan salah satu tanaman hias yang sudah mulai banyak dikenal oleh hampir semua masyarakat Indonesia. Berdasarkan hasil penelitian, bagian yang berkasiat dari tanaman lidah mertua adalah bagian daunnya karena mengandung saponin, kardenolin, polifenol dan abamagenin serta memiliki senyawa aktif Saponin, Polifenol, dan Flavonoid yang mampu bekerja sebagai antibakteri. Dalam penelitian Gitasari [5], tanaman lidah mertua memiliki aktivitas dalam menghambat pertumbuhan bakteri Staphylococcus aureus dengan kadar ekstrak etanol daun lidah mertua (Sansevieria trifasciata) yang diujikan dengan metode sumuran yaitu 5\%, 10\%, 20\%, dan 40\%. Ekstrak etanol daun lidah mertua (Sansevieria trifasciata) dengan konsentrasi 5\%, 10\%, 20\%, dan 40\% dapat menghambat pertumbuhan bakteri E. coli dengan rerata diameter zona hambat masing-masing yaitu 7,8 mm, $13 \mathrm{~mm}, 14,5 \mathrm{~mm}$, dan 17,3 mm sedangkan Streptococcus sp. dengan masing-gmasing rata-rata diameter zona hambat yaitu 4,6 mm, 9,6 mm, $13 \mathrm{~mm}$, dan 15,3 mm.

Pada saat ini penyakit yang disebabkan oleh infeksi bakteri masih menjadi masalah serius. Organisme penginfeksi, atau patogen, menggunakan sarana yang dimiliki inang untuk memperbanyak diri, yang pada akhirnya merugikan. Infeksi pada umumnya dapat diatasi dengan terapi, terutama menggunakan berbagai antibakteri. Masalah yang muncul dari penggunaan antibakteri atau antibiotik adalah resisitensi. Harga antibiotik yang mahal juga menjadi kendala bagi 
masyarakat kurang mampu untuk berobat, oleh karena itu, perlu dilakukan pencarian obat baru dari ekstrak tanaman seperti lidah mertua yang dapat digunakan untuk sebagai antibakteri untuk mengurangi resistensi bakteri [6].

\section{METODE PENELITIAN}

\section{1. ALAT DAN BAHAN}

Alat yang digunakan adalah timbangan digital Camry ACS-30-JC33, evaporator RV 10 Digital V, dan memmert oven laboratorium un 55 53l. Bahan yang digunakan adalah aquadest, salep bioplacenton, ekstrak lidah mertua etanol 70\%.

\section{2. CARA KERJA}

Pembuatan ekstrak. Daun lidah mertua yang telah dikeringkan dan dirajang kemudian ditimbang sebanyak 500 gram. Dimasukan kedalam wadah maserasi lalu direndam dengan pelarut etanol $70 \%$ sebanyak $3.750 \mathrm{ml}$ dengan perbandingan 1:7,5 dan dibiarkan selama 5 hari sesekali diaduk. Seluruh ekstrak yang didapat ditampung dan dipekatkan menggunakan rotary vacum evaporator serta disempurnakan pengeringannya di dalam oven suhu $40 \mathrm{oC}$ sehingga didapat ekstrak etanol (Crude extract) [7].

Perlakuan hewan uji. Disiapkan 5 ekor kelinci yang terdiri dari 2 kontrol, dan 3 perlakuan ekstrak lidah mertua. Hewan uji yang digunakan berumur $+2,5$ bulan yang telah dikarantinakan selama 7 hari untuk adaptasi. Sebanyak 5 ekor kelinci dibagi ke dalam 5 kelompok ( $n=1$ ekor). Kemudian kelinci dicukur bulunya pada daerah punggung dengan ukuran $+4 \mathrm{x} 2 \mathrm{~cm}$ dengan menggunakan alat cukur rambut sampai didapat kulit bersih halus dan bebas rambut /bulu. Sebelum dilukai kelinci dianastesi, kemudian daerah punggung yang sudah dicukur dilukai dengan koin panas ditempelkan di punggung kelinci selama 5 detik untuk mendapatkan luka bakar derajat 2 superficial. Basahi luka bakar dengan kain selama beberapa detik. Setiap kelompok diberi perlakuan dengan dosis 2 kali sehari secara topikal menggunakan kasa steril. Kelompok 1 (X) : Diberi bioplacenton pada luka bakar (kontrol positif), kelompok 2 (Y) : Diberi aquadest pada daerah luka bakar (kontrol negatif), kelompok 3 (A) : Diberi ekstrak lidah mertua 10\% pada daerah luka bakar, kelompok 4 (B) : Diberi ekstrak lidah mertua 15\% pada daerah luka bakar, kelompok 5 (C) : Diberi ekstrak lidah mertua 20\% pada daerah luka bakar. Perlakuan dilakukan selama 12 hari sambil diamati tiap 3 hari sebelum dan sesudah perlakuan dengan parameter kesembuhan yaitu semakin mengecilnya diameter luka bakar (fase proliferasi) [8]. Pengukuran rata-rata diameter luka bakar dilakukan seperti pada Gambar 1. [9].

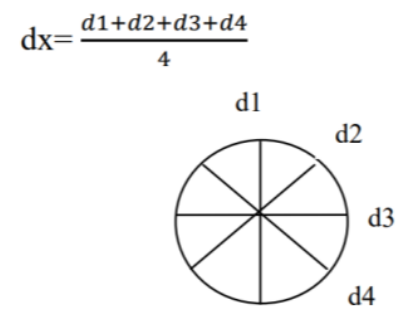

Gambar 1. Diameter luka bakar pada kelinci. 


\section{HASIL DAN PEMBAHASAN}

Sampel daun lidah mertua (Sansevieria trifasciata) diekstraksi dengan menggunakan metode maserasi dengan etanol 70\% sebagai pelarutnya. Maserasi merupakan metode penyarian simplisia yang sederhana dan mudah dilakukan. Etanol digunakan karena $70 \%$ bersifat semi polar yang mampu melarutkan golongan alkaloid, streroid, flavonoid, dan saponin [10].

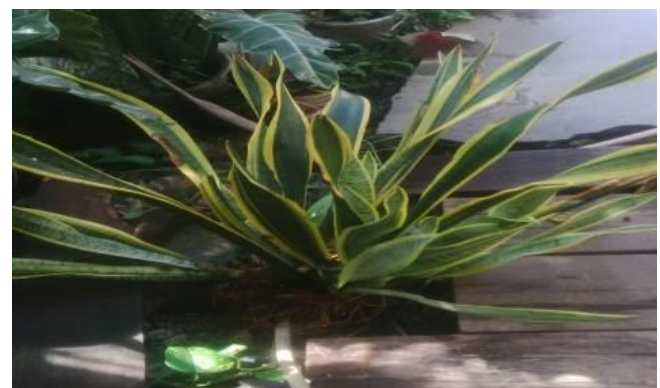

Gambar 2. Daun lidah mertua

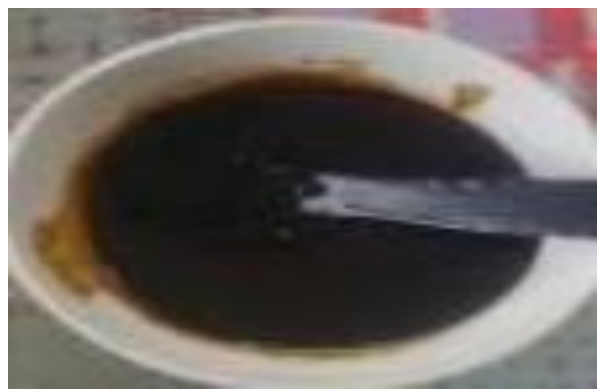

Gambar 3. Ekstrak daun lidah mertua

Ekstrak etanol 70\% daun lidah mertua mengandung senyawa saponin, flavonoid, steroid dan triterpenoid yang ditunjukkan dengan hasil positif [11]. Dey [12] juga melakukan analasisi GC-MS dengan hasil menunjukkan bahwa daun lidah mertua mengandung senyawa fenolik, alkaloid, terpenoid, flavonoid, steroid, glikosida dan saponin. Hasil ini sesuai dengan peneliti Yoshihiro et al. [13], bahwa Sansevieria mengandung saponin dan steroid. Demikian pula menurut Sastradipraja [14], kandungan lidah mertua antara lain polifenol dan saponin.

Kandungan alkaloid bersifat bakterisid karena memiliki kemampuan menghambat kerja enzim untuk mensintesis protein [15]. Kandungan saponin memiliki efek antibakteri untuk bakteriostatik yang bekerja dengan mengganggu stabilitas membran sel bakteri sehingga sel bakteri lisis [16]. Saponin juga bermanfaat untuk pembentukan kolagen yang akan mempengaruhi keberadaan sel sehingga akan mempercepat proses penyembuhan luka [17]. Adapun kandungan flavonoid juga sebagai antibakteri dengan cara membentuk senyawa kompleks terhadap protein ekstraseluler yang mengganggu keutuhan membran sel bakteri dan merusak membran sel tanpa bisa diperbaiki kembali [18].

Ervianingsih [19], pada penelitian sebelumnya menyatakan bahwa ekstrak buah tomat efektif menyembuhkan luka bakar pada hewan coba kelinci. Buah tomat mengandung alkaloid, flavonoid, dan saponin yang merupakan golongan senyawa yang samayang terdapat pada ektrak lidah mertua yang bersifat sebagai antibakteri.

Berdasarkan hasil data pada Tabel 1, semua perlakuan memberikan efek dapat mengobati luka bakar dengan hasil yang berbeda-beda. Pengukuran rata-rata luka bakar mengacu kepada Mappa et al. [9].

Hasil analisis statistik data hasil pengamatan pada Tabel 2 menunjukkan nilai $\mathrm{F}$ hitung lebih besar dari nilai $\mathrm{F}$ tabel $(30>2,35)$, maka $\mathrm{H}_{0}$ ditolak dan $\mathrm{H}_{1}$ diterima, dengan kata lain, terdapat perbedaan yang signifikan terhadap penyembuhan luka bakar pada kelinci antar kelompok perlakuan, maka dapat 
disimpulkan bahwa ekstrak lidah mertua dengan konsentrasi 10\%, 15\%, dan 20\% memiliki efek yang signifikan terhadap penyembuhan luka bakar.

Tabel 1. Rata-rata ukuran luka bakar

\begin{tabular}{|r|c|c|c|c|c|}
\hline \multirow{2}{*}{ Perlakuan } & \multicolumn{5}{|c|}{ Rata-rata pengamatan/pengukuran (cm) hari ke- } \\
\cline { 2 - 6 } & $\mathbf{1}$ & $\mathbf{3}$ & $\mathbf{6}$ & $\mathbf{9}$ & $\mathbf{1 2}$ \\
\hline $\mathrm{X}$ & 2 & 1,8 & 1,7 & 1,4 & 1,3 \\
\hline $\mathrm{Y}$ & 2 & 1,9 & 1,9 & 1,8 & 1,6 \\
\hline $\mathrm{A}$ & 2 & 1,9 & 1,9 & 1,7 & 1,6 \\
\hline $\mathrm{B}$ & 2 & 1,9 & 1,8 & 1,7 & 1,7 \\
\hline C & 2 & 1,8 & 1,6 & 1,4 & 1,1 \\
\hline
\end{tabular}

Keterangan:

$\mathrm{X}=$ kontrol positif

$\mathrm{Y}=$ kontrol negative

$\mathrm{A}=$ Diberi ekstrak lidah mertua $10 \%$

$\mathrm{B}=$ Diberi ekstrak lidah mertua $15 \%$

C = Diberi ekstrak lidah mertua 20\%

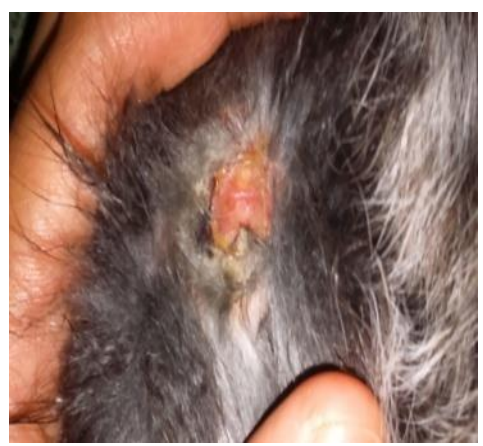

Gambar 4. Hasil uji penyembuhan luka bakar

Tabel 2. Hasil Uji Anova

\begin{tabular}{|r|c|c|c|c|c|}
\hline $\begin{array}{r}\text { SUMBER } \\
\text { KERAGAMAN }\end{array}$ & DB & JK & KT & F. HITUNG & F. TABEL \\
\cline { 1 - 1 } Kelompok & 4 & 0.27 & 0.06 & & 0.05 \\
\hline Perlakuan & 4 & 1.2 & 0.3 & \multirow{2}{*}{30} & \multirow{2}{*}{2.35} \\
\hline Galat & 16 & 0.09 & 0.01 & & \\
\hline Total & 24 & & & & \\
\hline
\end{tabular}

Keterangan :

$\mathrm{DB} \quad=$ Derajat Bebas

JK = Jumlah Kuadrat

KT = Kuadrat Tengah

Galat = Tingkat kesalahan

Kontrol positif dengan pemberian bioplacenton mengalami penyembuhan luka yang cukup baik selain karena mengandung neomycin sebagai antibiotik juga mengandung ekstrak placenta yang dapat mempercepat regenerasi sel dalam penyembuhan luka bakar.

Sedangkan pada kelompok kontrol negatif dengan pemberian aquades yang tidak memiliki efek pada penyembuhan luka, kelompok ini mengalami proses penyembuhan secara normal dimana luka bakar dengan derajat dua (superficial) 
dapat sembuh dalam 2 minggu, namun, penyembuhan tidak optimal seperti yang diperoleh pada pemberian ekstrak lidah mertua dan juga kontrol positif.

Adapun kelompok perlakuan ekstrak lidah mertua 10\%, 15\%, 20\% mengalami penyembuhan luka yang berbeda-beda dimana ekstrak lidah mertua $20 \%$ memberikan efek penyembuhan yang paling baik diantara beberapa kelompok perlakuan, hal ini dapat diasumsikan bahwa dengan ekstrak lidah mertua dengan konsentrasi $20 \%$ memiliki efek maksimal dalam memberikan efek terapi penyembuhan luka bakar.

Uji ANOVA yang dilakukan memberikan informasi tentang ada tidaknya beda antar rata-rata dari keseluruhan perlakuan, namun belum memberikan informasi tentang ada tidaknya perbedaan antara individu perlakuan. Uji BNT merupakan acuan dalam menentukan apakah ada tidaknya perbedaan antara individu perlakuan yang satu dengan invidu yang lain.

Untuk itu, analisis statistik dilanjutkan dengan uji BNT. Hasil analisis uji BNT pada tabel 3 menunjukkan bahwa kelompok perlakuan ekstrak dengan konsentrasi $10 \%$ dan $15 \%$ berbeda signifikan terhadap kelompok perlakuan ekstrak dengan konsentrasi $20 \%$, berarti bisa simpulkan bahwa semua perlakuan memberikan efek untuk menyembuhkan luka bakar.

Tabel 3. Hasil uji BNT

\begin{tabular}{|c|c|c|c|c|}
\hline $\begin{array}{l}\text { Kelompok } \\
\text { Perlakuan }\end{array}$ & $15 \%$ & $20 \%$ & Kontrol positif & Kontrol negatif \\
\hline $10 \%$ & 0,06 & $0,26 *$ & $0,16^{*}$ & 0,01 \\
\hline $15 \%$ & & 0,2 & 0,1 & 0,07 \\
\hline $20 \%$ & & & 0,1 & $0,27^{*}$ \\
\hline Kontrol positif & & & & $0,17^{*}$ \\
\hline Kontrol negatif & & & & \\
\hline
\end{tabular}

\section{KESIMPULAN}

Dari hasil penelitian dapat disimpulkan bahwa ekstrak lidah mertua dengan variasi konsentrasi $10 \%, 15 \%$ dan $20 \%$ memiliki efektivitas terhadap penyembuhan luka bakar yang diberikan secara topical pada hewan uji kelinci. Efek yang paling optimal diberikan oleh ekstrak dengan konsentrasi $20 \%$ dengan ratarata ukuran luka 1,58 .

\section{DAFTAR PUSTAKA}

[1]. Hatta, G. 2015. Pedoman Manajemen Informasi Kesehatan di Sarana Pelayanan Kesehatan. Jakarta, UI-Press.

[2]. Wong, DL 2008. Buku ajar Keperawatan Pediatrik. Edisi 6. Jakarta, EGC.

[3]. Soedarmo. 2008 Buku Ajar Infeksi dan pediatri topis, Badan Penerbit IDAI, Jakarta.

[4]. Church D., Elsayed S., Reid O., Winston B., Lindsay R. 2006. Burn Wound Infections. Clin. Microbiol. Rev, 19(2): 403-34. DOI: 10.1128

[5]. Gitasari, YD. 2011. Aktivitas Antibakteri Fraksi Aktif Daun Lidah Mertua (Sansevieria trifasciata Prain).Skripsi. Fakultas Matemika dan Ilmu Pengetahuan Alam. Institut Pertanian Bogor. 
[6]. Oktalia, Dwi Astuti. 2009. Isolasi Streptomyces Dari Rizosfer Familia Poaceae Yang Berpotensi Menghasilkan Antibiotik Terhadap Staphylococcus aureus. Skripsi. Fakultas Farmasi. Universitas Muhammadiyah Surakarta. Surakarta

[7]. Kemenkes RI [Kementerian Kesehatan Republik Indonesia]. 2013 Farmakope Herbal Indonesia. Edisi I. Suplemen III. Jakarta, Kemenkes RI.

[8]. Novaritasi. 2014. 'Uji Efektifitas Formulasi Gel Perasan Umbi Kentang (Solanum tuberosum L.) Terhadap Lama Kesembuhan Luka Bakar Pada Kelinci (Oryctolagus Cuniculus) Putih Jantan'.

[9]. Mappa, T., H.J., E. \& K.N., 2013, 'Formulasi Gel Ekstrak Daun Sasaladahan (Peperomia pellucid L.) dan Uji Efektivitasnya Terhadap Luka Bakar pada Kelinci (Oryctolagus cuniculus)', Jurnal Ilmiah Farmasi, 2(2): 49-56. DOI $: \underline{10.20885}$

[10]. Rahayu, I 2009, Praktis Belajar Kimia 1, Penerbit Departemen Pendidikan Nasional, Jakarta.

[11]. Komala O., Yulia I., Pebrianto R. 2012. Uji Efektivitas Ekstrak Etanol Daun Lidah Mertua (Sansevieria trifasciata Prain) Terhadap Khamir Candida albicans. Fitofarmaka, 2 (2): 146-152. DOI: 10.33751/jf.v2i2.169

[12]. Dey, B., R. Bhattacharjee, A. Mitra, R.K. Singla, A. Pal. 2014. Mechanistic Explorations of Antidiabetic Potentials of Sansevieria trifasciata. Indo Global Journal of Pharmaceutical Sciences, 4(2): 113-122

[13]. Yoshihiro M., Toshihiro I., Minpei K., Yutaka S. 1997. Pregnan glycosides from Sansevieria Trifasciata. Phytochemistry 44:107-111. https://doi.org/10.1016/S0031-9422(96)00477-3

[14]. Sastradipraja, S. 1997. Tanaman Hias, Bogor : Lembaga Biologi Nasional LIPI.

[15]. Kartikasari 2008. 'Pengaruh Ekstrak Batang Salvadora persica Terhadap Pertumbuhan Bakteri Streptococcus $\alpha$ - haemolyticus Hasil Isolasi Pasca Pencabutan Gigi Molar Ketiga Mandibula (Kajian In Vitro)'. Fakultas Kedokteran Gigi Universitas Gadjah Mada.

[16]. Ganiswara, GS 1995, Farmakologi dan Terapi. Jakarta, Gaya Baru.

[17]. Rachmawati S. 2007. 'Studi Makroskopi Dan Skrining Fitokimia Daun Anredera Cordifolia Steenis'.

[18]. Juliantina, FR 2008. 'Manfaat Sirih Merah Sebagai Agen Bakterial Terhadap Bakteri Gram Positif Dan Gram Negatif'. Jurnal Kedokteran dan Kesehatan Indonesia. DOI : 10.20885

[19]. Ervianingsih \& Abdul Razak. 2017. Uji Efektivitas Ekstrak Buah Tomat (Solanum lycopersicum) Terhadap Penyembuhan Luka Bakar Pada Hewan Uji Kelinci (Oryctolagus cuniculus). Borneo Journal Pharmascientech, 1 (2): 1-9. 